\title{
Non-pharmacologic Approaches to Dysphagia in Patients with Multiple Sclerosis: A Systematic Review
}

\author{
Multipl Sklerozlu Hastalarda Disfajiye Yönelik Non-farmakolojik Yaklaşımlar: \\ Sistematik Bir Derleme
}

(1) Gülşah Kesik, (1) Leyla Özdemir

Hacettepe University Faculty of Nursing, Department of Internal Medicine Nursing, Ankara, Turkey

\begin{abstract}
Dysphagia, which is frequently seen in patients with multiple sclerosis (MS) and defined as difficulty in swallowing, can lead to serious complications such as aspiration pneumonia, dehydration, malnutrition, and increases morbidity and mortality rates and decreases quality of life. In patients with MS, dysphagia can be intervened by pharmacologic or surgical methods; this symptom can also be controlled by non-pharmacologic and non-invasive methods such as sensory stimulation techniques, swallowing maneuvers, dietary modifications, and positional swallowing techniques. No previous systematic reviews on the effects of non-pharmacologic or non-invasive methods on dysphagia in MS have been published. The main objective of this study was to summarize and qualitatively analyze published studies on non-pharmacologic or non-invasive methods effects for dysphagia in MS. Within the scope of the study, a detailed literature review was performed and four studies were examined considering the inclusion criteria. The non-pharmacologic applications in the studies are as follows: Traditional dysphagia rehabilitation methods, which include methods such as oral motor exercises and swallowing maneuvers; electrical stimulation, and respiratory muscle exercises. In these studies, dysphagia and/or swallowing-related quality of life were measured with similar scales. It is seen that all of the related interventions have a significant effect on dysphagia and/or swallowing-related quality of life in patients with MS. In conclusion, in light of the information in the literature, non-pharmacologic methods can be said to be effective in the control of dysphagia in patients with MS. In addition, it may be suggested to conduct experimental and more comprehensive studies in this field.
\end{abstract}

Keywords: Dysphagia, nursing care, multiple sclerosis, non-pharmacologic approaches, systematic review

\section{$\ddot{O} \mathbf{z}$}

Multipl sklerozlu (MS) hastalarda sıklıkla görülen ve yutma güçlüğü olarak tanımlanan disfaji; aspirasyon pnömonisi, dehidratasyon, malnütrisyon gibi ciddi komplikasyonlara yol açabilen, morbidite ve mortalite oranlarını artıran ve yaşam kalitesini düşüren bir semptomdur. MS'li hastalarda disfajiye farmakolojik veya cerrahi yöntemlerin yanı sıra, non-farmakolojik ve non-invaziv yöntemlerle de müdahale edilebilmektedir. Disfajinin yönetiminde kullanılan temel nonfarmakolojik yöntemler; duyusal uyarma teknikleri, yutma manevraları, diyet modifikasyonları ve pozisyonel yutma teknikleri olarak sıralanabilir. Yapılan literatür taramasında, MS'li hastalarda disfajinin tedavi ve bakımında non-farmakolojik ve non-invaziv yöntemlere ilişkin bir sistematik derlemeye ulaşılamamıştır. Bu çalışmanın temel amacı, disfajinin kontrolünde literatürde yer alan non-farmakolojik girişimlerin incelenmesidir. Çalışma kapsamında detaylı bir literatür taraması yapılmış, dahil edilme kriterleri göz önüne alınarak 4 araştırma incelenmiştir. İncelenen çalışmalardaki non-farmakolojik yöntemler; oral motor egzersizler, yutma manevraları gibi yöntemleri içeren geleneksel disfaji rehabilitasyon yöntemleri, elektrik stimülasyonu ve solunum kasları egzersizleridir. Çalışmalarda, disfaji ve/veya yutma ilişkili yaşam kalitesi benzer skalalarla ölçülmüştür. İlgili girişimlerin tamamının, MS'li hastalarda disfaji ve/veya yutma ilişkili yaşam kalitesi üzerinde anlamlı düzeyde etki ettiği görülmektedir. Sonuç olarak, literatürdeki bilgiler ışı̆̆ında, MS’li hastalarda disfajinin kontrolünde non-farmakolojik yöntemlerin etkin olduğu söylenebilir. Ayrıca, bu alanda deneysel tasarımlı ve daha kapsamlı araştırmalar yapılması önerilebilir.

Anahtar Kelimeler: Disfaji, hemşirelik bakımı, multipl skleroz, non-farmakolojik yöntemler, sistematik derleme

Address for Correspondence/Yazışma Adresi: Gülşah Kesik, Nurse, Hacettepe University Faculty of Nursing, Department of Internal Medicine Nursing Ankara, Turkey

Phone: +90 5380828183 E-mail: gulsah_dogann@outlook.com ORCID: orcid.org/0000-0002-5748-8225

Received/Gelis Tarihi: 14.02 .2020 Accepted+/Kabul Tarihi: 27.08 .2020

${ }^{\circ}$ Copyright 2021 by Turkish Neurological Society

Turkish Journal of Neurology published by Galenos Publishing House. 


\section{Introduction}

Multiple sclerosis (MS) is a chronic disease that progresses with attacks and remissions. Full recovery cannot be achieved despite intensive treatments. Patients with MS can show many different symptoms from the moment of diagnosis. One of the most important of these symptoms is dysphagia, which develops due to the disruption of the process of activating the muscles used in swallowing by the stimulation of the swallowing reflex originating from the brainstem when the food is chewed and ready to be swallowed, due to myelin degeneration $(1,2,3,4,5)$. Dysphagia is very important in the treatment and care of patients with MS because it is a common symptom with long-term exposure and can cause many vital complications $(3,4)$. It is known that dysphagia is more common in patients with MS with high Expanded Disability Status Scale (EDSS) scores and relatively severe brainstem involvement. According to the literature, although not generalizable to all patients with MS, the prevalence of dysphagia varies between $33 \%$ and $43 \%$, especially in groups with high symptom severity. It has been reported that dysphagia may last from 2-3 weeks to 2-4 months in exacerbation periods and may continue in remission periods by becoming chronic $(5,6,7)$.

Dysphagia increases mortality and morbidity by causing complications such as aspiration pneumonia, dehydration, malnutrition, and swallowing anxiety, as well as adversely affecting nutrition, causing pain and discomfort in the patient, and decreasing the quality of life $(8,9)$. Various methods classified as objective and subjective are used to define dysphagia. Objective screening methods used in the evaluation of dysphagia can be listed as physical examination, comprehensive neurological evaluation, videofluoroscopic evaluation of swallowing, and electromyography $(8,9,10)$. Subjective screening methods are scales developed for bedside evaluation of swallowing and dysphagia and can be used in various disease groups. To evaluate dysphagia in patients with MS, screening tools such as the Eating Assessment Tool (EAT10), Dysphagia in Multiple Sclerosis Questionnaire, Mann Assessment of Swallowing Ability (MASA), and Penetration- Aspiration Scale (PAS) are used $(11,12,13)$.
The need for non-pharmacologic, non-invasive approaches and complementary and integrative methods in symptom management has increased due to the lack of complete recovery in patients with MS despite drug treatments (e.g. corticosteroids, intravenous immunoglobulin, biologic agents). In addition to pharmacologic and invasive methods in the treatment and care of dysphagia, which is one of the important symptoms to control in patients with MS, non-pharmacologic and non-invasive methods such as sensory stimulation techniques, swallowing maneuvers, diet modifications, and positional swallowing techniques are also recommended $(8,11,13)$. These methods can be preferred more than pharmacologic and invasive methods because they do not cause adverse effects, they are practical applications that patients can integrate into their daily lives, and they do not cause extra cost. However, few studies have examined the effectiveness of nonpharmacologic methods on dysphagia in patients with MS (14). Also, no systematic review of non-pharmacologic approaches in the management of dysphagia in patients with MS could be found in our literature review. The main purpose of this study was to systematically examine the non-pharmacologic approaches used in the management of dysphagia, which is an important symptom in patients with MS.

\section{Material and Method}

\section{Design}

This systematic review was based on the PRISMA model (15).

\section{Determining The Research Question}

To determine the framework of the research question, research question components (PICOS) were created by the author including population $(\mathrm{P})$, interventions $(\mathrm{I})$, comparators $(\mathrm{C})$, outcomes $(\mathrm{O})$ and study designs (S) (Table 1).

English keywords were scanned in Medical Subject Headings index and Turkish keywords were scanned in Turkey Science Terms. "multiple sclerosis", "dysphagia", "swallowing disorders", "nursing" and "clinical investigation", and their translations were used as Turkish and English keywords for scanning.

\section{Table 1. Determination of research question}

\begin{tabular}{|ll|}
\hline Question components & Definition \\
P: Population & Target group; \\
& Dysphagic patients with MS \\
& Interventions; \\
& Non-pharmacologic Interventions \\
C: Comparators & Comparators; \\
& $\begin{array}{l}\text { Dysphagia levels before non-pharmacologic intervention and dysphagia levels } \\
\text { after non-pharmacologic intervention in patients with MS }\end{array}$ \\
O: Outcomes & Outcomes; \\
& Dysphagia scale scores \\
& Study designs; \\
S: Study Designs & Semi-experimental studies, \\
& Randomized controlled studies, \\
& Pre-test and post-test controlled studies, \\
& Mixed-type studies. \\
MS: Multiple sclerosis & \\
\hline
\end{tabular}




\section{Literature Review Steps}

After determining the PICOS and keywords for preliminary research on the subject, the stage of the literature review was started. Cochrane, PubMed, ScienceDirect, CINAHL, Embase, Turkish Medline and ULAKBIM Medical databases were scanned with keywords determined.

\section{Inclusion and Exclusion Criteria}

Inclusion criteria:

1. Studies having experimental or quasi-experimental study design,

2. Studies having been performed in dysphagic patients with MS,

3. Studies using at least one non-pharmacologic intervention,

4. Studies using at least one data collection tool that measures the level of dysphagia,

5. Studies having been published in Turkish or English,

6. Studies having been performed between 2006-2020.

Exclusion criteria:

1. Studies having been published in a language other than Turkish or English,

2. Studies without an experimental design,

3. Studies published before 2006,

4. Studies having been performed in a group other than dysphagic patients with MS,

5. Studies not using a specific measuring tool to measure dysphagia,

6. Studies in which a pharmacological intervention was used.

\section{Selection of Studies}

A detailed literature search was performed by the authors of the article, using the keywords mentioned above and filtering the year options, and a total of 3.234 articles were found. The articles were separated according to their titles and the abstracts $(n=397)$ that were most relevant to the subject were recorded. After the abstracts were carefully examined by the authors, studies with pharmacologic interventions $(n=48)$, with invasive interventions (8), with different patient groups $(n=54)$, non-invasive studies $(n=186)$, studies for which full-texts were not available $(n=5)$, studies published in a language other than Turkish and English $(n=6)$, and studies that did not use a scale to measure dysphagia $(n=86)$ were excluded. The full texts of the remaining $(n=4)$ articles were read in detail and were included in the scope of this review because they met all inclusion criteria (Figure 1).

\section{Examination of Studies}

In order to gather the data of the four studies included in the study, a standard form was created by the researchers by scanning the literature. The form included the non-pharmacologic method applied, the year and country of the study, the design of the study, the application period, the scale used and, the research outcome (Table 2).

\section{Results}

Although it was seen that there were 3.234 articles in the search performed on Cochrane, PubMed, ScienceDirect, CINAHL, Embase, Turkish Medline and ULAKBIM Medical databases, only four studies were found that met the inclusion criteria. Three of these studies were randomized controlled studies and one was performed with a non-randomized pre-test and posttest comparative study design. The non-pharmacologic methods used in the studies included traditional dysphagia rehabilitation methods such as oral motor exercises and swallowing maneuvers, electrical stimulation, and respiratory muscle exercises. A flow chart was followed in which the studies were examined according to the non-pharmacologic method used in the interpretation of the findings.

\section{Traditional Dysphagia Rehabilitation Methods}

In a double-blind randomized controlled study that was conducted by Tarameshlu et al. (16) in 2016 in Iran with 20 patients with MS aged age between 20 and 60 years, oral motor exercises and swallowing maneuvers (Mendelson's maneuver, Supraglottic swallowing, effort swallowing) were applied to the intervention group. Routine care methods such as dietary modifications and appropriate positioning were applied in the patients. According to the evaluations made with the MASA and the PAS, as a result of the 6-week application, the level of dysphagia significantly decreased in the intervention group compared with the patients in the control group. The limitation of this study was the small sample size. As a result of the study, it was stated that there was a need for randomized studies in which dysphagia rehabilitation methods were evaluated separately with larger samples (16).

\section{Electrical Stimulation}

In a non-randomized pre-test and post-test comparative study conducted by Bogaardt et al. (17) in 2009 in The Netherlands with 25 patients with MS with an average age of 53.1 years, neuromuscular electrostimulation (NMES) was applied to the patients. NMES was applied non-invasively to the jaw and neck

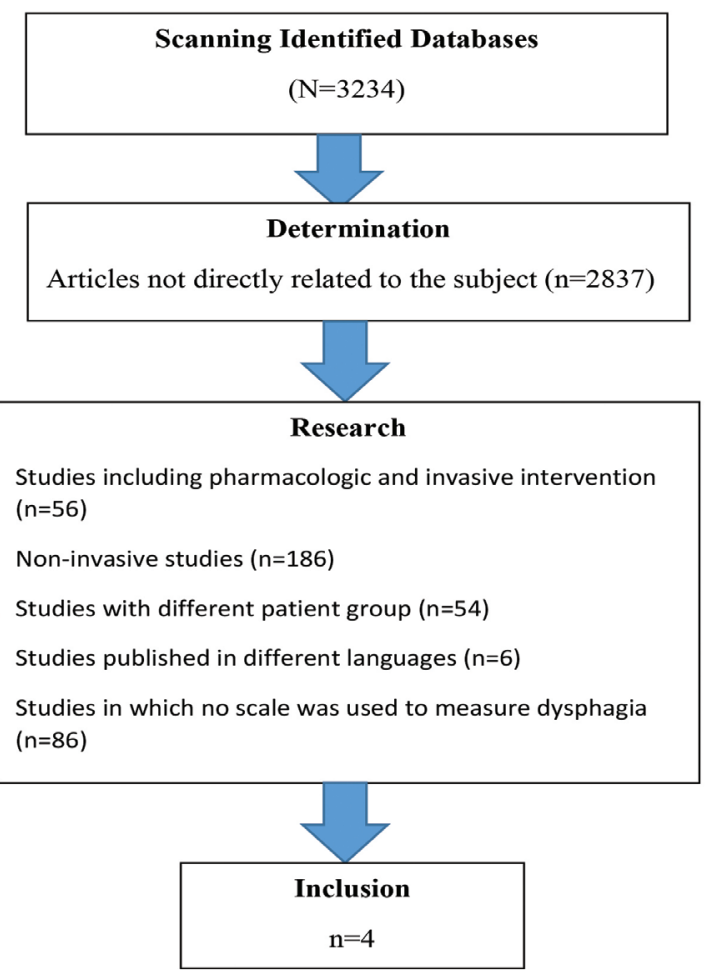

Figure 1. Selection of studies 


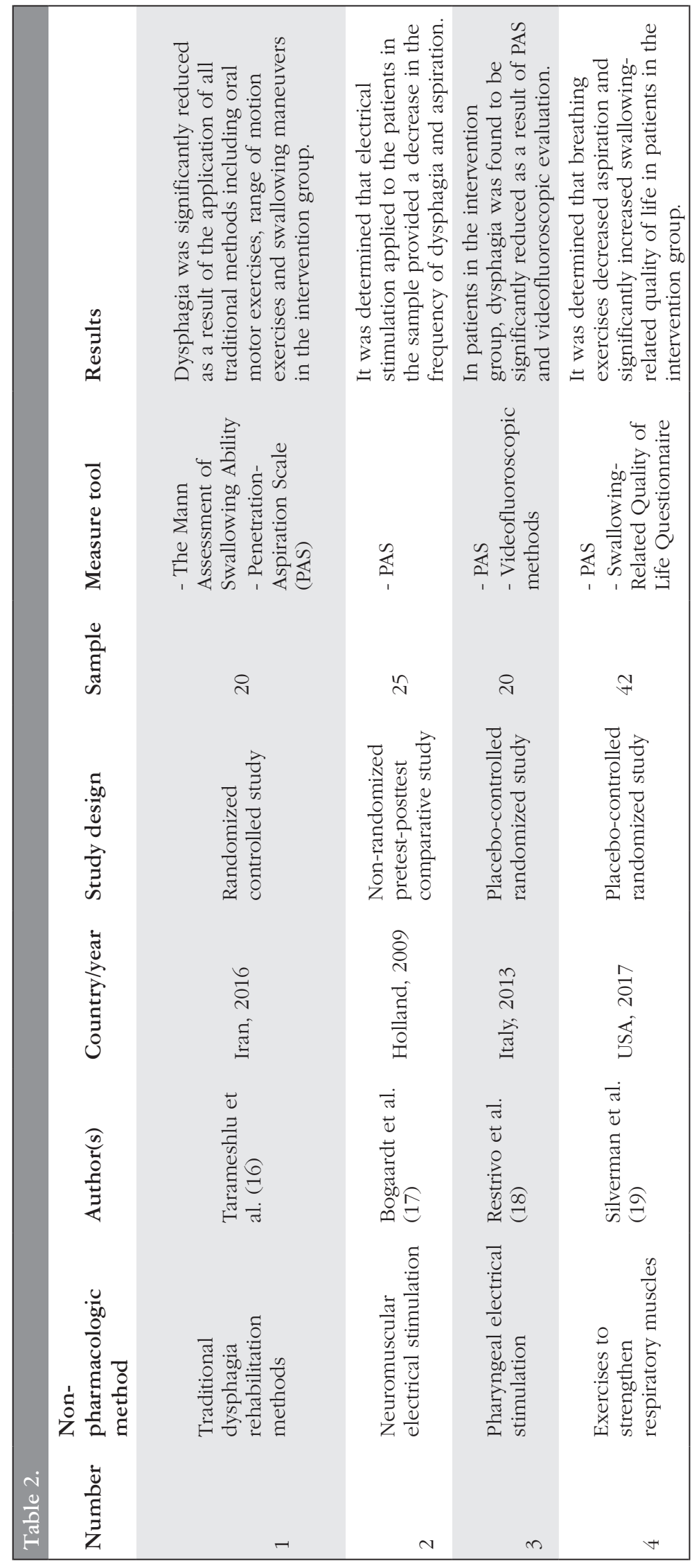

regions of the patients with the help of an electrode in six sessions of 20 minutes for 3 weeks. When the pre-test and post-test results of the study were compared, it could be said that the positive effect of NMES on dysphagia in patients with MS was statistically significant (17).

Another electrical stimulation application was performed by Restivo et al. (18) with 20 patients in the United States of America in 2012. Of the patients in the study sample, 13 were female, seven were male, and their average age was 39.7 years. That study was planned as a placebo-controlled randomized study. Pharyngeal electrical stimulation (PES) was applied to 10 patients in the intervention group in 10-minute sessions for 5 days, and patients in the control group were treated with a fake electrode that did not conduct an electrical current. The swallowing status of the patients was evaluated using PAS in addition to radiologic methods, and the positive effect of PES on dysphagia in patients with MS was found to be statistically significant (18).

\section{Respiratory Muscle Exercises}

In a placebo-controlled randomized study conducted by Silverman et al. (19) in 2017 with 42 patients with MS in the United States, patients in the intervention group underwent a positive pressure device to strengthen their respiratory muscles at home, 5 sets and 5 times per day, a total of 25 times per day. They were asked to open the OneWay valve by blowing forcefully to strain the respiratory muscles. Patients in the placebo group were asked to perform the same applications with a similar device without pressure. The results of this study were evaluated using PAS and the Swallowing-Related Quality of Life Scale. It was found that exercises forcing the respiratory muscles decreased the risk of dysphagia and aspiration, and significantly increased swallowing-related quality of life in patients with MS (19).

\section{Discussion}

In the literature review, it was seen that there were many descriptive studies on the etiology, prevalence, and complications of dysphagia in patients with MS $(20,21,22,23)$. Almost all of these studies suggested that dysphagia should be diagnosed early and controlled by pharmacologic or non-pharmacologic methods before it caused complications. However, there are few interventional studies on the treatment and care of dysphagia in patients with MS, and most involve pharmacologic or invasive interventions (14). Four articles were reviewed in this systematic review on the treatment and care of dysphagia symptoms, which were frequently seen in patients with MS. It was demonstrated that non-pharmacologic interventions reduced the symptoms of dysphagia, the frequency of aspiration, and increased swallowing-related quality of life. As a result of the literature search, it is seen that the non-pharmacologic approach to dysphagia in patients with MS includes the combined application of methods such as oral motor exercises, which are called traditional dysphagia rehabilitation methods, swallowing maneuvers, application of electrical stimulation, and exercises for respiratory muscles. 
In light of the literature, it can be concluded that methods such as swallowing maneuvers, oral motor exercises, feeding position, and diet modification are very important approaches in the control of dysphagia. However, no study separately measured the effectiveness of these interventions for patients with MS. In the study by Tarameshlu et al. (16), it was seen that many interventions were applied in combination. This situation makes it impossible to comment on the exact effectiveness of each initiative. However, in the literature, there are studies in which these interventions are examined separately in different disease groups $(10,13,24,25)$.

In a systematic review published in 2017, Karaali et al. (24) reported that Mendelson's maneuver was effective in the care of dysphagia seen in patients with head and neck cancer. Selçuk (13) reported that Mendelson's maneuver had a significant effect on patients with dysphagia. At the same time, studies in the literature indicate that this maneuver needs to be studied with different patient groups $(13,24,25)$. In the literature, there is no study that directly examined the effectiveness of this maneuver in dysphagic patients with MS.

In a study conducted by Yakşi et al. (26) in 2018 with dysphagic patients with stroke, it was revealed that postural adaptation maneuvers had a significant effect on swallowing function. In this study, it was found that in addition to the chin tuck posture, rotation of the head to the affected side positively affected swallowing in dysphagic patients with stroke (26). However, in the literature review, there is no study examining the effectiveness of feeding positions in dysphagia rehabilitation in patients with MS.

Again, one of the effective methods in the management of dysphagia developing in different patient groups in the literature is the application of thermal tactile stimulation. Thermal tactile stimulation, one of the sensory stimulation techniques, is a non-invasive and non-pharmacologic nursing practice that is frequently recommended in care for dysphagia (10). In the study by Teismann et al. (10), which examined the mechanism of action of thermal tactile stimulation, it was revealed that this practice provided faster stimulation of swallowing muscles with increased bihemispheric activation of the left somatosensory cortical areas and facilitated the swallowing action. However, no study investigating the effectiveness of this application in patients with MS has been found in a literature search.

Although there is no study investigating dysphagia rehabilitation in patients with MS in the literature, complementary and integrative methods are preferred and up-to-date applications in symptom management in many chronic diseases. Complementary and alternative methods include applications such as acupuncture, yoga, meditation, relaxation exercises, which have no adverse effects and can be easily performed by patients in their daily lives. In a study conducted by Chan et al. (20) in 2012, acupuncture was found to be effective in dysphagia management in neurologic diseases. However, there is no study investigating the effect of acupuncture in dysphagia rehabilitation in patients with MS. Similarly, the effect of complementary and integrative methods such as yoga, meditation, and relaxation exercises on various symptoms in MS has been investigated, but no study has been found that demonstrates their effects on dysphagia symptoms.

\section{Limitations}

Because only four studies meeting the inclusion criteria were reached in the literature review, the authors included all experimental studies, not limited to randomized controlled trials; therefore, the strength of the studies, blinding, and bias risk could not be examined. In addition, because there is no interventional study examining the effect of non-pharmacologic approaches in dysphagia in patients with MS in our country, only publications in English could be included in the scope of the review. In addition, in the studies examined, patient populations were not stratified according to EDSS or brain stem involvement. The findings of this systematic review cannot be generalized to the population because there is heterogeneity in the sample of the studies examined.

\section{Conclusion and Recommendations}

The results of this systematic review revealed that traditional dysphagia rehabilitation methods such as oral motor exercises and swallowing maneuvers (Mendelian maneuver, supraglottic swallowing, effort swallowing), electrical stimulation, and respiratory muscle exercises were effective in dysphagia management. The differences in the sample size of these studies and the lack of a standard in the implementation period were among the important results of this study. Again, some of the important results of this review were that studies examining nonpharmacologic approaches to dysphagia in patients with MS were insufficient in number and there were no published studies in this field in our country. Therefore, randomized controlled studies with high-level evidence are needed to examine the effectiveness of nonpharmacologic methods in dysphagia rehabilitation in patients with MS. In view of the findings of this systematic review, it is recommended to conduct studies investigating various alternative methods, primarily non-pharmacologic methods, which have been shown to be effective on dysphagia in other neurologic diseases. In addition, in studies on dysphagia symptoms in patients with MS, it is recommended to determine the patient population according to EDSS scores to enable generalizing the findings to the population.

Ethics

Peer-review: Externally and internally peer-reviewed.

\section{Authorship Contributions}

Concept: G.K., L.Ö., Design: G.K., L.Ö., Data Collection or Processing: G.K., Analysis or Interpretation: G.K., Literature Search: G.K., Writing: G.K., L.Ö.

Conflict of Interest: No conflict of interest was declared by the authors.

Financial Disclosure: The authors declared that this study received no financial support.

\section{References}

1. Plowman EK, Tabor LC, Robison R, et al. Discriminant ability of the Eating Assessment Tool-10 to detect aspiration in individuals with amyotrophic lateral sclerosis. Neurogastroenterol Motil 2016;28:85-90.

2. Rofes L, Arreola V, Mukherjee R, Clave P. Sensitivity and specifity of the Eating Assessment Tool and the volume-viscosity swallow test for clinical evaluation of oropharyngeal dysphagia. Neurogastroenterol Motil 2014;26:1256-1265.

3. Cheney DM, Siddiqui MT, Litts JK, Kuhn MA, Belafsky PC. The ability of the 10-Item Eating Assessment tool (EAT-10) to predict aspiration risk in persons with dysphagia. Ann Otol Rhinol Laryngol 2015;124:351-354. 
4. Kaspar K, Ekberg O. Identifying vulnerable patients: role of the EAT-10 and the multidisciplinary team for early intervention and comprehensive dysphagia care. Nestle Nutr Inst Workshop Ser 2012;72:19-31.

5. Carrión S, Cabré S, Monteis R, et al. Oropharyngeal dysphagia is a prevalent risk factor for malnutrition in a cohort of older patients admitted with an acute disease to a general hospital. Clin Nutr 2015;4:436-442.

6. Bergamaschi R, Crivelli P, Rezzani C, et al. The DYMUS questionnaire for the assessment of dysphagia in multiple sclerosis. J Neuro Sci 2008;269:4953.

7. Arvedson J, Clark H, Lazarus C, Schooling T, Frymark T. The effects of oralmotor exercises on swallowing in children: an evidence-based systematic review. Dev Med Child Neurol 2010;52:1000-1013. Wertman E, Zilber N, Abramsky O. An association between MS and type 1 diabetes mellitus. J Neurol 1992;239:43-45.

8. Sayaca Ç. Yutma Bozukluklarının Rehabilitasyonunda Propriyoseptif Nöromusküler Fasilitasyon Tekniğinin Etkisinin Araştırılması (Doktora Tezi). Ankara: Hacettepe Üniversitesi; 2018.

9. Budak E, Taymur İ, Önen S, Kanat B, Akdeniz Ö, Demirci H. Symptoms of swallowing anxiety in panic disorder patients and associated psychopathologic factors. Eat Weight Disord 2018;23:487-497.

10. Teismann K, Steinsträter $\mathrm{O}$, Warnecke $\mathrm{T}$, et al. Tactile thermal oral stimulation increases the cortical representation of swallowing. BMC Neurosci 2009; 10:71.

11. Tenekeci E, Kara B, Çetiz A, et al. Validity and reliability of the Turkish version of the questionnaire for the assessment of dysphagia in multiple sclerosis. Arch Neuropsychiatr 2018;55:243-247.

12. Demir N. Reliability and validity of the Turkish eating assessment tool (T-EAT-10) Dysphagia 2016;31:644-649.

13. Selçuk B. Dysphagia in Stroke. Turk J Phys Med Rehab 2006;52(Suppl B):B38-B44. 25.

14. Alali D, Ballard K, Bogaardt H. Treatment effects for dysphagia in adults with multiple sclerosis: a systematic review. Dysphagia 2016;31:610-618.

15. Moher D, Liberati A, Tetzlaff J, Altman DG, The PRISMA Group. Preferred reporting items for systematic reviews and meta-analyses: the prisma statement. PLoS Med 2009;6:e1000097.
16. Tarameshlu M, Ghelichi L, Azimi AR, Ansari NN, Khatoonabadi AR. The effect of traditional dysphagia therapy on the swallowing function in patients with Multiple Sclerosis: a pilot double-blinded randomized controlled trial. J Bodyw Mov Ther 2019;23:171-176.

17. Bogaardt $H$, van Dam D, Wever $\mathrm{N}$, et al. Use of neuromuscular electrostimulation in the treatment of dysphagia in patients with multiple sclerosis. Ann Otol Rhinol Laryngol 2009;118:241-246.

18. Restivo D, Casabona A, Centonze D, et al. Pharyngeal electrical stimulation for dysphagia associated with multiple sclerosis: a pilot study. Brain Stimul 2013;6:418-423.

19. Silverman E, Miller S, Zhang Y, et al. Effects of expiratory muscle strength training on maximal respiratory pressure and swallow-related quality of life in individuals with multiple sclerosis. Mult Scler J Exp Transl Clin 2017;3:2055217317710829.

20. Chan S, Or K, Sun W, et al. Therapeutic effects of acupuncture for neurogenic dysphagia_a randomized controlled trial. J Trad Chin Med 2012;32:25-30.

21. Keage M, Delatycki M, Corben L, Vogel A. A systematic review of selfreported swallowing assessments in progressive neurological disorders. Dysphagia 2015;30:27-46.

22. Nina S. Dysphagia management for progressive neurological conditions. Nurs Stand 2006;29:53-57.

23. Blackington E, McCormick T, Willson B, et al. Oropharyngeal dysphagia in the elderly: Identifying and managing patients at risk. Adv Nurse Practit 2001;9:42-48.

24. Karaali E, Özcan Ö, Ilgın D. Investigation of rehabilitation methods used in dysphagia following head and neck cancer. Turkısh Journal Of Physiotherapy And Rehabilitation 2017;28:57-58.

25. Alali D, Ballard K, Bogaardt H. The frequency of dysphagia and its impact on adults with multiple sclerosis based on patient-reported questionnaires. Mult Scler Relat Disord 2018;25:227-231.

26. Yakşi E, Kurul R, Avcı Ş, Ögün M. Disfajik inmeli bireylerde kullanılan kompansatuvar postürün yutma üzerine etkisi. Konuralp Med J 2018;10:6164. 